\title{
Aspects of Hexavalent Chromium Pollution of Thebes Plain Aquifer, Boeotia, Greece
}

\author{
Dimitrios I. Koilakos \\ Department of Water Resources and Agricultural Mechanics, Agricultural University of Athens, \\ Iera Odos 75 Street P.C., 11855 Athens, Greece; dikoilakos@aua.gr; Tel.: +30-210-6014082
}

Received: 12 June 2017; Accepted: 8 August 2017; Published: 16 August 2017

\begin{abstract}
The present work focuses on the environmental problem of Thebes Plain-since considerable amounts of $\mathrm{Cr}(\mathrm{VI})$ have been reported-and tries to find out the reasons of such a phenomenon and the sources of the pollution. For this issue, a complete chemical analysis of 20 samples from the study area was conducted as well as an isotopic analysis of $\mathrm{Cr}$ and $\mathrm{Sr}$ isotopes. Hexavalent chromium pollution can be triggered by human pollutant activity or specific geological environments. Stable $\mathrm{Cr}$ isotopic analysis gave $\delta^{53} \mathrm{Cr}$ positive values in several samples which supports the second hypothesis, but the limitations of that theory do not allow safe conclusions in all cases. Nitrates and $\mathrm{Sr}$ ratios suggest fertilizer contamination and the presence of $\mathrm{SiO}_{2}$-leaching of silicate rocks.
\end{abstract}

Keywords: hexavalent chromium; strontium; isotopes; geogenic pollution; nitrates; leaching

\section{Introduction}

Hexavalent chromium pollution is a common phenomenon, since several case studies can be mentioned from all around the world such as Urania State of Sao Paolo, Brazil [1]; La Specia Province, Italy [2]; Leon Valley, Mexico [3]; and Mojave Desert, California, USA [4]. Also in the USA., in four major lakes of the Mississippi, pollutant toxic metals including chromium have been detected [5]; additionally, pollutant substances have been found in bottom sediments of Lake Symsar, Poland [6]. In several areas of Greece, $\mathrm{Cr}(\mathrm{VI})$ has been detected, such as Central Euboea and Avlonas [7,8].

$\mathrm{Cr}$ (VI) pollution may cause several diseases such as cancer; leuchemy, if it comes into contact with blood; and if inhaled (in the form of gas), it can destroy the lag [9,10], which means that the measurement and the monitoring of that parameter is essential not only for environmental protection but also for public health. The international, European and Greek legislations impose certain guidelines for Cr (VI) [11-13].

There are several reasons for $\mathrm{Cr}(\mathrm{VI})$ pollution. According to the literature, industrial activity creates wastes of $\mathrm{Cr}(\mathrm{VI})$ mainly due to treatment of inorganic and organic matters [14]. Another pollutant factor is agricultural activity since several fertilizers and agrochemicals contain $\mathrm{Cr}$ (VI) [15]. This has been reported in fertilizers of the study area [16]. Also, over pumping and the mixture of aquifers are also pollutant factors [17]. Mining activity is another factor [18]. Stock farm activity throughout manures, stables and slaughterhouses can also generate $\mathrm{Cr}$ (VI). Sewers and cesspools, especially from urban networks, directly lead the humid elements into the groundwater. Another factor is the improper manufacture of drillings which can result in the mixture of aquifers and pipe leaching.

$\mathrm{Cr}$ (VI) may be generated by the rocks, especially those containing $\mathrm{Cr}$ such as peridotites or serpentines on ophiolitic belts $[19,20]$. Nature may generate $\mathrm{Cr}(\mathrm{VI})$ in the ground water and four geological environments have been reported [21,22] which may produce natural $\mathrm{Cr}(\mathrm{VI})$ : arid alluvial basins such as those in southwest USA; saline brines in evaporate basins; chromite ore bodies; serpentinite ultramafic terrains. In the first two environments, the redox conditions tend to favor the 
generation and preservation of $\mathrm{Cr}(\mathrm{VI})$ while in the last two, the hydrolysis of chromites and peridotites is the basic mechanism of $\mathrm{Cr}(\mathrm{VI})$ enrichment. Natural Cr (VI) has been detected on Presidio of San Francisco. Cr (VI) was attributed to natural factors because no human sources were present. On the other hand, the serpentine bedrock could provide $\mathrm{Cr}(\mathrm{VI})$, as proved by leaching tests on borehole cores [20].

The study area is Thebes Plain located on Boeotia Prefecture-Greece. $\mathrm{Cr}$ (VI) pollution has been reported in boreholes of Avlonas and the town surroundings of Thebes [23,24]. In the study area groundwater, the $\mathrm{Cr}$ (VI) levels come up to $204 \mu \mathrm{g} / \mathrm{L}$ as a maximum value [25]. Other researches and independent works $[26,27]$ also give evidence of the issue. Last but not least, Institute of Geological and Mineralogical Exploration of Greece (IGME) has worked on this area and came to some serious conclusions in 2010 [28].

The study area is a complex environment where the geogenic factor plays an important role in the presence of hexavalent chromium in soil and groundwater. The development of ophiolites and peridotites, which are characterized by the presence of chromium, is the main geogenic factor. Additionally, the weathering of the ophiolites has contributed to the enrichment of the soils with chromium. Apart from the natural factor, human contribution plays an important role, including industries, stock-farms and ranches and quarries. Last but not least, the study area is under intense agricultural exploitation. All these factors contribute to $\mathrm{Cr}(\mathrm{VI})$ pollution in the study area.

The modern theory of chromium stable isotopes may answer if $\mathrm{Cr}$ (VI) has natural or human origin. Several case studies in Mojave Desert and Snake River in USA [4,29] have been carried out in this direction. In Greece, the issue has also been under discussion [7,30]. Another question which had to be answered was if the calcium/magnesium ratios matched those of peridotites. For that purpose, it was suggested to conduct further isotope analysis and measure isotopes of strontium and dissolved $\mathrm{SiO}_{2}$ to check if the values match and leaching of silicate rocks indeed takes place.

\section{Generally Information about Chromium}

Chromium is found in lithosphere in low concentrations. The highest concentrations are found in magmatic rocks $(198 \mathrm{mg} / \mathrm{kg})$ and clay $(120 \mathrm{mg} / \mathrm{kg})$, while the lowest ones are found in carbonate rocks $(7.08 \mathrm{mg} / \mathrm{kg})$ and evaporites $(10.6 \mathrm{mg} / \mathrm{kg})$. The major chromium minerals are chromite $\left(\mathrm{FeOCr}_{2} \mathrm{O}_{3}\right)$ which is dominant in peridotites and crocoite $\left(\mathrm{PbCrO}_{4}\right)$ which can be found in the oxidation zone of lead deposits [22]. In sea water, the concentration is about $0.2 \mu \mathrm{g} / \mathrm{L}$, whereas in surface and ground waters the chromium concentrations have an average concentration of $0.4 \mu \mathrm{g} / \mathrm{L}$. In California's boreholes, there have been detected values up to $21 \mu \mathrm{g} / \mathrm{L}$ [31]. The usual concentrations on potable water do not exceed $5 \mu \mathrm{g} / \mathrm{L}$. The European Union classes chromium as a toxic substance and imposes $50 \mu \mathrm{g} / \mathrm{L}$ as an upper limit for total chromium on potable water.

\subsection{Oxidation States of Chromium}

Chromium in nature occurs in two oxidation states $[19,22,31]$ : the trivalent and the hexavalent form. The trivalent form is more common in soils. In the study area, the concentrations in soil are between 32 and $906 \mathrm{mg} / \mathrm{kg}$ d.w. [32]. The average of chromium in soils worldwide is $54 \mathrm{mg} / \mathrm{kg}$ while in study area is $280 \mathrm{mg} / \mathrm{kg}$ d.w. [32].

In aquatic environments, chromium occurs also in two oxidation states, i.e., $\mathrm{Cr}$ (III) in chromic compounds and $\mathrm{Cr}(\mathrm{VI})$ in anionic form in chromates $\mathrm{CrO}_{4}{ }^{2-}$ and di-chromates $\mathrm{Cr}_{2} \mathrm{O}_{7}{ }^{2-}$ [22]. $\mathrm{Cr}$ (VI) may be transformed to $\mathrm{Cr}$ (III) and vice versa. In the first case, $\mathrm{Cr}$ (VI) is reduced to $\mathrm{Cr}$ (III), while in the second case, $\mathrm{Cr}$ (III) is oxidized to $\mathrm{Cr}$ (VI). The oxidation of $\mathrm{Cr}$ (III) to $\mathrm{Cr}$ (VI) or the reduction of $\mathrm{Cr}$ (VI) to $\mathrm{Cr}$ (III) requires another redox couple which accepts or gives the necessary electrons. The significant redox couples are the following [33-35].

$$
\mathrm{H}_{2} \mathrm{O}-\mathrm{O}_{2}, \mathrm{Mn}(\mathrm{II})-\mathrm{Mn}(\mathrm{IV}), \mathrm{NO}_{2}-\mathrm{NO}_{3}, \mathrm{Fe}(\mathrm{II})-\mathrm{Fe}(\mathrm{III}), \mathrm{S}^{2-}-\mathrm{SO}_{4}{ }^{2-}, \mathrm{CH}_{4}-\mathrm{CO}_{2}
$$


Under normal conditions in the $\mathrm{Cr}-\mathrm{H}_{2} \mathrm{O}-\mathrm{O}$ system, the zone of $\mathrm{Cr}(\mathrm{VI})$ stability ranges in a wide area in comparison with the trivalent form. The species of $\mathrm{Cr}(\mathrm{VI})$ appear in oxidant conditions $(\mathrm{Eh}>0)$ and alkaline $\mathrm{pH}>6$. The fate of chromium in the environment may also be controlled by the Eh and $\mathrm{pH}$ conditions. In natural waters and average redox conditions, a common transformation [22] takes place according to reaction 1 :

Reaction 1:

$$
\mathrm{Cr}(\mathrm{OH})_{3}+\mathrm{H}_{2} \mathrm{O} \rightarrow \mathrm{Cr}(\mathrm{OH})_{4}{ }^{2-}+\mathrm{H}^{+}
$$

This reaction takes place in relatively high Eh conditions at pHs between 6.5 and 8.5 [34]. According to laboratory experiments, ${ }^{51} \mathrm{Cr}$ (III) has been oxidized in five days at $\mathrm{pH} 8$ to 10 .

Dissolved oxygen has been found to oxidize $\mathrm{Cr}$ (III) according to experiments in aquatic solutions. In natural waters, the rate of oxidation is too slow and other factors have to coexist in order for such transformation to take place [35]. In soils and aquatic environments, the absorption of trivalent chromium from oxides of Manganium is the first step for it to transform (oxidation) to hexavalent. This process takes place in the presence of iron oxides, and clay minerals [36]. The following equation has been proposed $[37,38]$ after long experiments.

Reaction 2:

$$
7 \mathrm{Cr}_{3}+36 \mathrm{MnO}_{2}+12 \mathrm{H}_{2} \mathrm{O} \rightarrow 21 \mathrm{HCrO}_{4}^{-}+18 \mathrm{Mn}^{2+}+3 \mathrm{H}^{+}
$$

This process takes place relatively quickly. According to experiments [19,33], the rate of oxidation in the presence of $\mathrm{MnO}_{2}$ depends on its quantity. At the ratio $\mathrm{MnO}_{2}: \mathrm{Cr}=200: 1$, the added $\mathrm{Cr}(\mathrm{VI})$ oxidized totally after $42 \mathrm{~min}$, while in 10 times higher concentration of $\mathrm{MnO}_{2}$ only 3 min was required [35].

The reduced sulfur $\left(\mathrm{S}, \mathrm{S}^{2-}, \mathrm{H}_{2} \mathrm{~S}, \mathrm{~S}_{2} \mathrm{O}_{3}{ }^{2-}\right.$ ) may be a basic factor in the reduction of $\mathrm{Cr}$ (VI) to $\mathrm{Cr}$ (III). Laboratory studies have reported that the reduction of $\mathrm{Cr}(\mathrm{VI})$ involving sulfides is initially rapid, slows down in a few minutes, but reaches completion after one day [35].

Iron (II) is a major factor in the reduction of Cr (VI) to Cr (III) [35,39]. Dissolved Fe (II) ions in environmental waters may be generated by the discharges of some industrial wastes, but also may result from the weathering of $\mathrm{Fe}(\mathrm{II})$-containing minerals. Numerous minerals in geologic materials contain Fe (II) for $\mathrm{Cr}$ (VI) reduction, including silicates, oxides, or sulfides [40]. Cr (VI) reduction via Fe (II) in silicate minerals (e.g., biotite in solution rather than at the mineral surface) takes place according to the following chemical reaction [40].

Reaction 3

$$
3 \mathrm{FeO}+6 \mathrm{H}^{+}+\mathrm{Cr}(\mathrm{VI})(\mathrm{aq})=\mathrm{Cr}(\mathrm{III})(\mathrm{aq})+3 \mathrm{Fe}(\mathrm{III})(\mathrm{aq})+3 \mathrm{H}_{2} \mathrm{O}
$$

This reduction is complete after $2 \mathrm{~min}$; the end-products of this reaction are Fe (III) and $\mathrm{Cr}$ (III) which precipitate in acidic solution [41].

Finally, nitrates could pose a potential problem in $\mathrm{Cr}(\mathrm{VI})$. If direct reduction of $\mathrm{Cr}$ (VI) were to dominate, then $\mathrm{NO}_{3}{ }^{-}$could potentially inhibit $\mathrm{Cr}(\mathrm{VI})$ reduction since $\mathrm{Cr}(\mathrm{VI})$ and $\mathrm{NO}_{3}{ }^{-}$have similar redox potentials [42].

\subsection{Isotopic Chemistry}

Stable Isotopes Chromium Systematics

Chromium has four stable isotopes with the following abundances [21]: ${ }^{500} \mathrm{Cr} 4.35 \%,{ }^{52} \mathrm{Cr} 83.79 \%$, ${ }^{53} \mathrm{Cr} 9.50 \%,{ }^{54} \mathrm{Cr} 2.36 \%$

The value $\delta^{53} \mathrm{Cr}$ is crucial for distinguishing the pollution source.

The $\delta^{53} \mathrm{Cr}$ value is calculated as follows (according to National Institute of Standards and Technology Standard Reference Material)

$$
\frac{R_{\text {sample }}}{R_{o}}=\left(\frac{C}{C_{0}}\right)^{a-1}
$$


where:

$R_{\text {sample: }}$ the ${ }^{53} \mathrm{Cr} /{ }^{52} \mathrm{Cr}$ ratio in the sample water

$R_{o}$ : the initial ${ }^{53} \mathrm{Cr} /{ }^{52} \mathrm{Cr}$ ratio

$C$ : the concentration of $\mathrm{Cr}$ in the sample water

$C_{o}$ : the initial $\mathrm{Cr}$ concentration of the sample

$\alpha$ : Cr fractionation factor

$\delta^{53} \mathrm{Cr}$ is related with $R_{\text {sample }}$ with the following equation

$$
R_{\text {sample }}=\frac{\delta^{53} \mathrm{Cr} \times R_{\text {std }}}{1000}+R_{\text {std }}
$$

where $R_{\text {std }}$ is the $\mathrm{Cr}^{53} / \mathrm{Cr}^{52}$ ratio of the National Institute of Standards and Technology Standard Reference Material 979, equal with 0.113418 which represents the average natural abundance of $\mathrm{Cr}$ on the Earth's crust.

When pollution is anthropogenic, the $\delta^{53} \mathrm{Cr}$ value is near to zero $[4,43,44]$. This happens because the industrial materials have the properties of chromite whose $\delta^{53} \mathrm{Cr}$ value is near to zero; additionally, no significant fractionation takes place during the industrial activities $[43,44]$. The theory of isotopes has to be used with great attention since hexavalent chromium tends to oxidize to trivalent chromium under suitable conditions, this results in fractionation of the considering sample and it may give positive $\delta^{53} \mathrm{Cr}$ values [21] even if the $\mathrm{Cr}(\mathrm{VI})$ concentrations are from anthropogenic sources.

\subsection{Strontium Isotopes Systematics}

Sr isotopes are considered to be an excellent tracer in hydrogeology [45,46]. In contrast to stable chromium isotopes, they do not fractionate considerably in nature. Groundwater acquires dissolved $\mathrm{Sr}$ in two hydrogeological environments. The first is the recharge area through infiltration and the percolation process, while the second is found along the flow path, through dissolution or ion exchange with minerals. The $\mathrm{Sr}$ isotopes are used as tracers in hydrogeological applications because they give insight into the water-rock interaction process. In Grand Sasso, Central Italy, Sr isotopes are used as tracers to find the recharge area. This took place by following the highest ${ }^{87} \mathrm{Sr} /{ }^{86} \mathrm{Sr}$ isotopic ratios. In another case study in Monte Volture volcano, Italy, Triassic dolomite limestones such as those of the study area, are found to have a $0.70882{ }^{87} \mathrm{Sr} /{ }^{86} \mathrm{Sr}$ ratio [47].

Several ranges are given in the literature for ${ }^{87} \mathrm{Sr} /{ }^{86} \mathrm{Sr}$ ratios. Carbonate rocks have ${ }^{87} \mathrm{Sr} /{ }^{86} \mathrm{Sr}$ values between 0.7068 and 0.7094 [48-50]. In silicate rocks, such as granite and gneiss, ${ }^{87} \mathrm{Sr} /{ }^{86} \mathrm{Sr}$ ratios range between 0.7135 and 0.717 [48,51]. For basalts, ${ }^{87} \mathrm{Sr} /{ }^{86} \mathrm{Sr}$ ratios range between 0.703 and 0.705 [52]. The anthropogenic influence on ${ }^{87} \mathrm{Sr} /{ }^{86} \mathrm{Sr}$ ratios is also evident: fertilizers contain very large contents of $\mathrm{Sr}(3-1500 \mathrm{ppm})$ [50] and the isotopic ratio ranges between 0.70794 and 0.70950 . The carbonate amendments used in agriculture are of ${ }^{87} \mathrm{Sr} /{ }^{86} \mathrm{Sr}$ ratios around 0.70987 [52]. In rainwater, ${ }^{87} \mathrm{Sr} /{ }^{86} \mathrm{Sr}$ ratios are around 0.709 and 0.7106 . In seawater, ${ }^{87} \mathrm{Sr} /{ }^{86} \mathrm{Sr}$ ratios are around 0.709 [50].

\section{Geology and Hydrogeology}

The study area belongs geotectonically to the Pelagonian zone and is structured by Mesozoic, Tertiary and Quaternary formations. Mesozoic formations consist of carbonate rocks, limestones, dolomites, peridotites, ophiolite mélanges and flints as Figure 1 depicts [53]. The Tertiary formations consist of marls and sandstone clays. The Quaternary formations are represented by clastic sediments, debris and Holocaine deposits. The description of the geological formations from the newer to the older formations goes as follows.

Alluvium: These formations are the alluvial deposits, the debris, and the slide rocks. There are loose deposits that consist of clastic polymict coarse material, i.e., gravels, breccia and grits, but it also contains thinner material such as sand and clay. This material originates from the surrounding hills and the mountains. The depth of the deposits ranges from a few meters to more than $100 \mathrm{~m}$ at the 
central part of the basin. At the surface, there is fertile cultivated land rich in clay. The coarse material originates from the erosion of limestones, dolomites, and ophiolites of the surrounding hills.

Pliocene-Pleistocene deposits: The lower Pliocene formations are formed in lake and lagoon environments and appear as layers, while Pleistocene formations deposited on terrestrial environments appear as thick layers. They are alternated with thinner material in circles (thin, coarse). At the eastern part, the lower Pliocene deposits dominate, while at the western part Pleistocene deposits occur.

Flysch: It is undivided and its age has been determined by the geological mapping and the fossils of Paleocene-Eocene. The flysch transits to the following limestones.

Limestones-dolomites: They underlie the flint series and include:

Low-middle Jurassic limestones of middle thickness contained in the upper and the lower part flints

Low Jurassic-Upper Triassic carbonate rocks are dark colored limestones with medium thickness in the upper part. Crystalline limestones underlie them and overlie colored limestones, dolomite limestones and dolomites.

It has been observed by borehole sections that the limestones are expanding below the alluvial deposits to the west and southwest part of the basin [53].

Ophiolites-flints: The ophiolite mélange consists of peridotites which have been under serpentinization, diabases and cherts. This system is more than $300 \mathrm{~m}$ deep. The ophiolites occur at the northeastern part of the area in Mouriki Village.

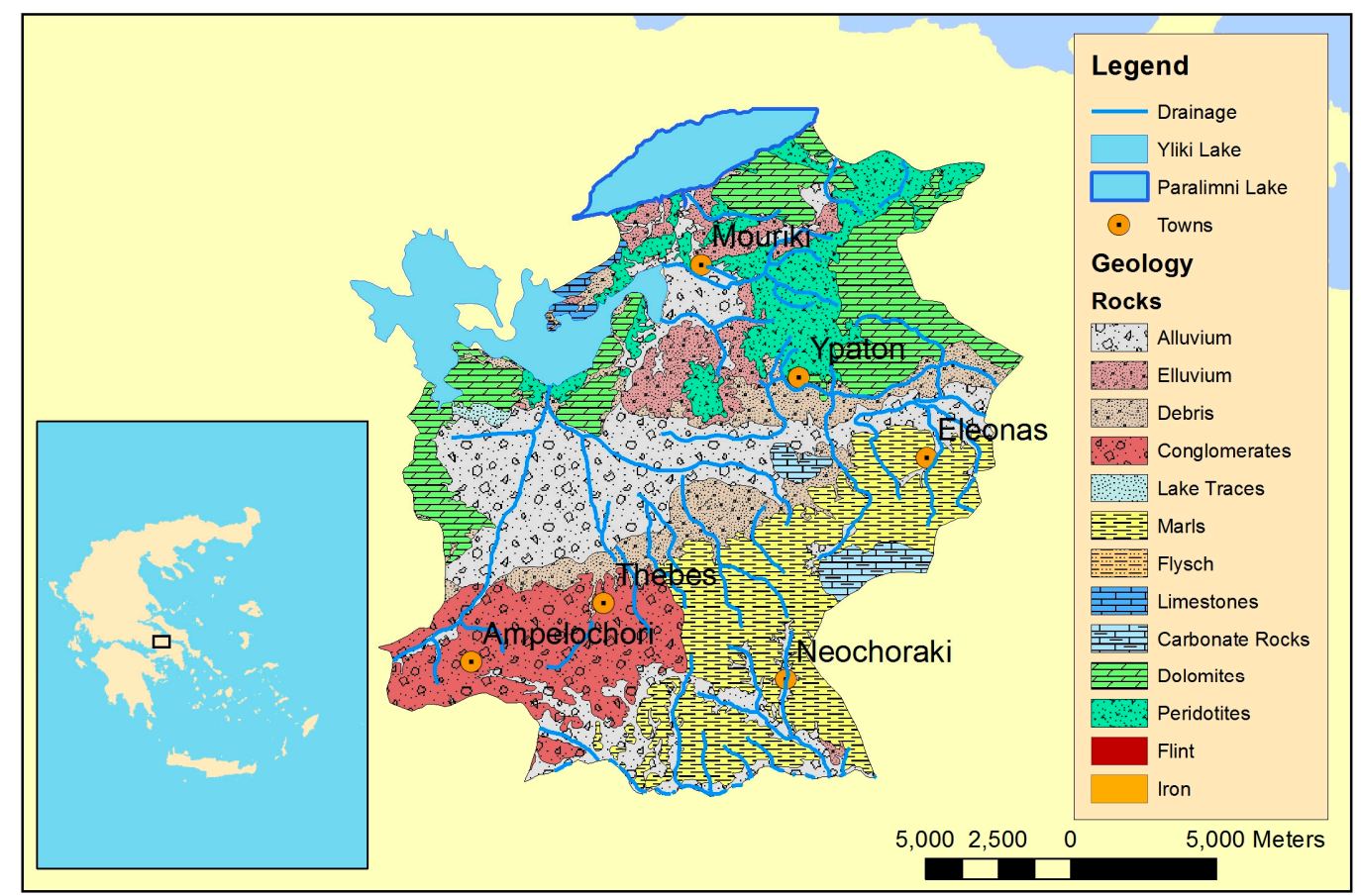

Figure 1. Geological map of the study area.

\subsection{Hydrogeological Aspects}

According to IGME, a geological map in the area develops four kinds of aquifers. Firstly, porosity aquifers occur which are divided into high productive aquifers and extensive productive aquifers (alluvium on Figure 1). Secondly, karstic formations appear which are divided into high productive aquifers and extensive productive aquifers. These formations appear on the limestone and dolomite formations. Hard rock practical permeable formations occur in the Mouriki Revenia area and these formations are considered to be responsible for natural Cr (VI). Practically impermeable rocks such as marls of Neocene exist between the areas of Thebes and Neochoraki. 
The porous aquifers are of particular hydrogeological interest due to their wide occurrence and thickness. Inside these formations, alternated aquifers exist which are under exploitation through several wells and boreholes. Their critical supply is more than $100 \mathrm{~m}^{3} / \mathrm{h}$ [54]. The carbonate aquifers are highly productive aquifers due to their intense karstification. Boreholes deeper than $170 \mathrm{~m}$ present critical recharge more than $120 \mathrm{~m}^{3} / \mathrm{h}$ [54]. Finally, the ophiolite mélange hosts aquifers of limited productivity and the critical recharge ranges between 10 and $35 \mathrm{~m}^{3} / \mathrm{h}[54]$.

\subsection{Sampling Campaign}

In the dry period of 2012, 20 samples were collected. We have focused on the polluted areas of Thebes plain and the peridotite zone on Mouriki. This sampling campaign aimed at focusing on particular areas of intense pollutant phenomena. All the points are illustrated in Figure 2. The particular areas were indicated after year-long research on the study area, taking into consideration all the available publications and data $[7,16,23-27]$. In the field, the coordinates of the water points were estimated with a GPS device. The electric conductivity, the temperature, $\mathrm{pH}$, redox, and dissolved oxygen were measured with special equipment. The water samples were collected in polyethylene bottles of $1 \mathrm{~L}$ and preserved in the refrigerator until further analysis. In separate bottles of $100 \mathrm{~mL}$, similar samples which had undergone a $45 \mathrm{~nm}$ filtering, have been collected [55].

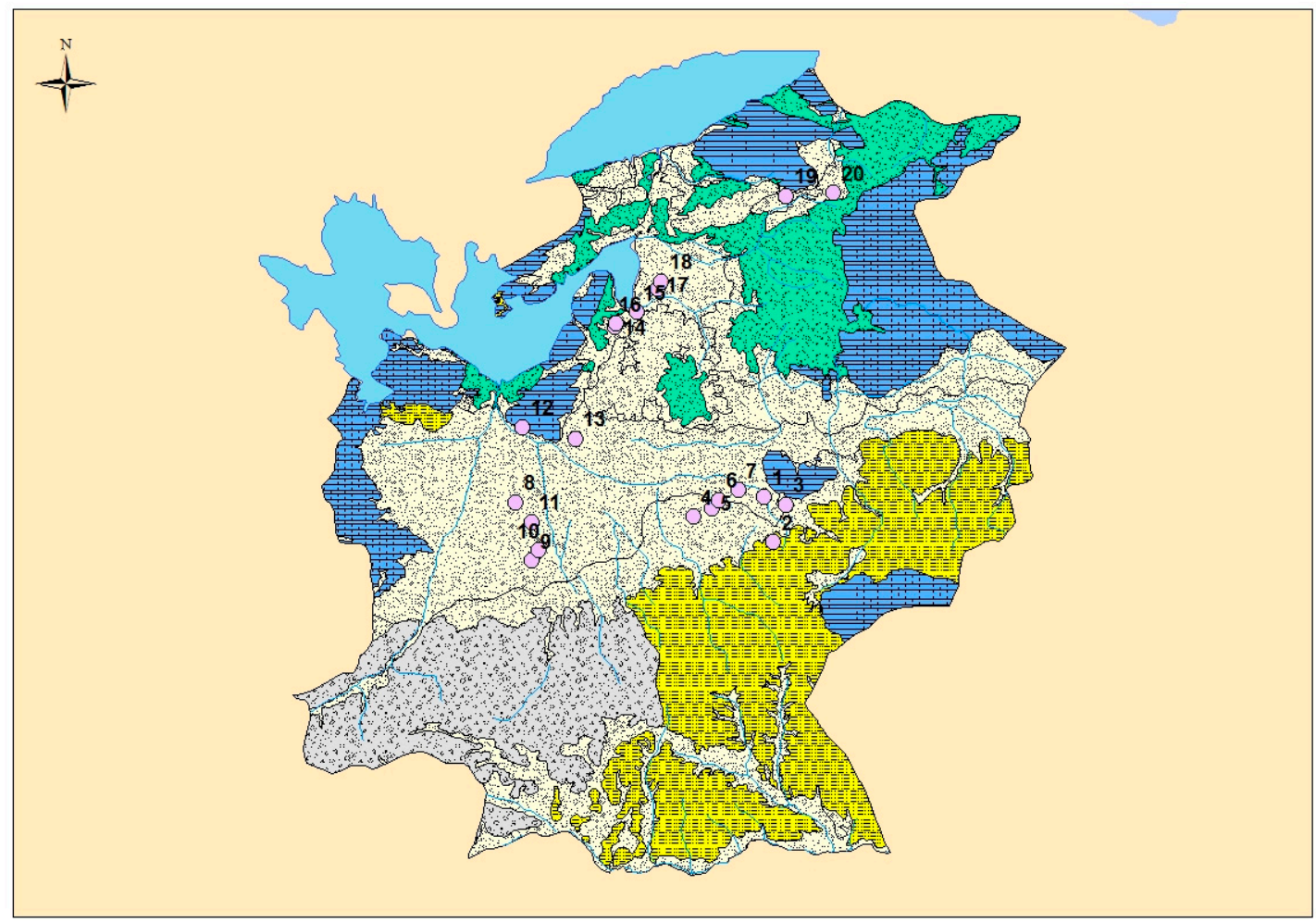

Figure 2. Sampling points.

\subsection{Anthropogenic Sources of Pollution}

There are several sources of anthropogenic chromium in the study area. According to the Institute of Geological and Mineralogical Research (IGME 2010), their spatial distribution is as shown in Figure 3. Almost all the recorded sources release hexavalent chromium to the environment. We will focus on industrial units which release: $\mathrm{As}, \mathrm{Cd}, \mathrm{Cr}, \mathrm{Cu}, \mathrm{F}, \mathrm{Hg}, \mathrm{Ni}, \mathrm{Pb}, \mathrm{Zn}, \mathrm{NH}_{3}, \mathrm{NO}_{\mathrm{x}}, \mathrm{SO}_{\mathrm{x}}$ and on the farms which produce: $\mathrm{As}, \mathrm{B}, \mathrm{Cd}, \mathrm{Cr}, \mathrm{Cu}, \mathrm{Hg}, \mathrm{Ni}, \mathrm{P}, \mathrm{Pb}, \mathrm{Sb}, \mathrm{Se}, \mathrm{Zn}, \mathrm{NH}_{3}$.

Agricultural activity is intense in the Alluvial Basin and Mouriki region. The pollutant sources that IGME recorded are gathered in Mouriki and the west part of the Basin. The Mesovouni area 
(east part) has a quarry and some ranches. The west part (Thebes) has ranches, quarries, a cemetery, Thebes dump and an industry.

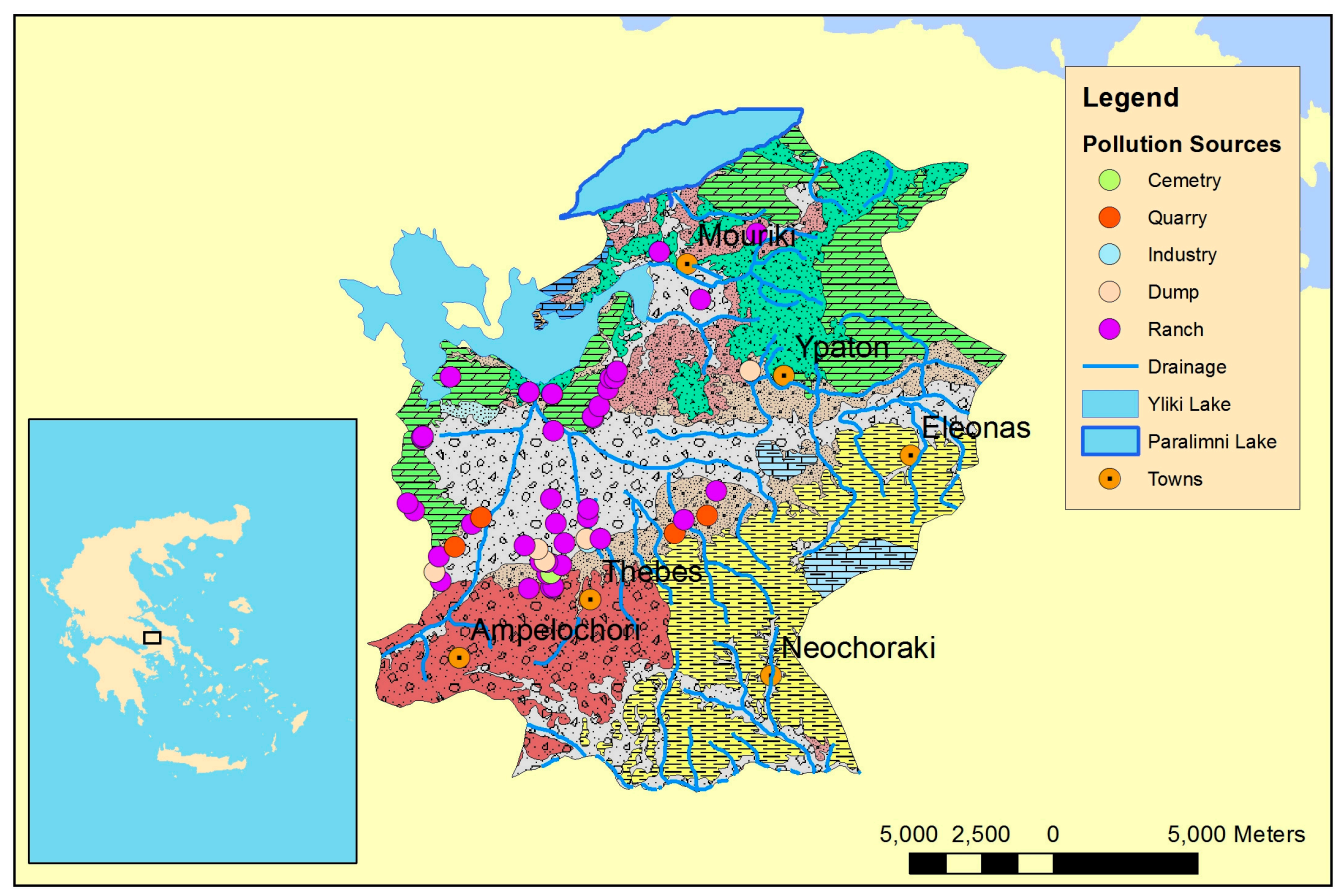

Figure 3. Sources of anthropogenic pollution according to the Institute of Geological and Mineralogical Research (IGME) 2010.

\section{Material and Methods}

\subsection{Major Chemistry and Heavy Metals}

The anion, cation and heavy metal analyses were carried out in the Laboratory of Agricultural Hydraulics in the Agricultural University of Athens. For anion and cation determination, we used ion chromatography. The anions $\mathrm{Cl}^{-}, \mathrm{NO}_{3}{ }^{-}, \mathrm{NO}_{2}{ }^{-}$and $\mathrm{SO}_{4}{ }^{2-}$ were measured by ion chromatography with a simple injection of the sample. The methodology required an eluent which consisted of $0.137 \mathrm{~g}$ sodium carbonate and $0.168 \mathrm{~g}$ sodium hydrogen carbonate diluted in $1000 \mathrm{~mL}$ ultrapure water. Additionally, a stock of $2.5 \mathrm{~mL} \mathrm{H}_{2} \mathrm{SO}_{4}$ diluted in $1000 \mathrm{~mL}$ ultrapure water was necessary in order for the process to be carried out with suppression.

The cations $\left(\mathrm{Li}^{+}, \mathrm{Na}^{+}, \mathrm{NH}_{4}{ }^{+}, \mathrm{Mn}^{2+}, \mathrm{K}^{+}, \mathrm{Ca}^{2+}\right.$ and $\left.\mathrm{Mg}^{2+}\right)$ have been measured using another method. The eluent consisted of $0.6 \mathrm{~g}$ tartaric acid and $0.167 \mathrm{~g}$ dipicolinic acid diluted in $1000 \mathrm{~mL}$ ultrapure water. The cation process has undergone no suppression. The ion chromatograph was constructed by Metrohm in Stockholm of Swiss. It was consisted of an IC Interface, Detector, Separation center, liquid handling unit and pump. The system was connected to a computer and printer.

Polarography was used for $\mathrm{Cr}(\mathrm{VI})$ and heavy metal determination. For $\mathrm{Cr}$ (VI) determination, the following methodology was used: a buffer was produced which contained $1.64 \mathrm{~g}$ oxic sodium, $1.96 \mathrm{~g}$ DTPA (Pentetic acid) $21.3 \mathrm{~g}$ nitric acid in a $100 \mathrm{~mL}$ volumetric flask which was filled up to the mark with ultrapure water and mixed with a stirrer. We prepared a mixture containing $10 \mathrm{~mL}$ of the measured sample and $2.5 \mathrm{~mL}$ buffer. The $\mathrm{pH}$ should be regulated to $6.2 \pm 0.1$. A standard for the estimation of hexavalent Chromium was used and inserted when standard addition was required. The calculations and the presentation of the results were applied by computer software [56].

Polarography was also used for Lead, Copper and, Zinc. These metals were estimated under a specific method. For their measurement, we introduced $10 \mathrm{~mL}$ of the sample and we added $0.5 \mathrm{~mL}$ acetate buffer. We measured the $\mathrm{pH}$ of the mixture; the final $\mathrm{pH}$ was controlled by importing a small 
quantity of acetic oxide in order to be about $4.6 \pm 0.2$ [57]. The polarograph (Metrohm, Stockholm, Swiss) was a VA 797 Computrace model, connected with a computer such as an Ion Chromatograph.

Titration has been used in order to measure the bicarbonate anion. The indicator was blue phenolphthalein and the titrator $0.1 \mathrm{~N} \mathrm{HCl}$. The titration took place until the sample became blue. $\mathrm{Cr}(\mathrm{VI}), \mathrm{Cr}_{\text {tot }}, \mathrm{Fe}_{\text {tot }}$ and $\mathrm{SiO}_{2}$ were measured by a spectrophotometer. For $\mathrm{Cr}$ (VI), a Chroma-ver powder was used, while for $\mathrm{Fe}_{\text {tot }}$, the appropriate indicator was used. $\mathrm{For}_{\mathrm{SiO}_{2}}$ and $\mathrm{Cr}_{\text {tot }}$, the methods were more complex and appropriate methodologies have been followed [58]. All the methods that we used were suggested by the relative protocols in compliance with the instructions of the instruments and the requirements of the methodologies. The samples were analyzed for $\mathrm{Cr}$ (VI) no later than $24 \mathrm{~h}$ after the samples' collection as suggested by the relative protocol [55]. For $\mathrm{Cr}$ (VI) and $\mathrm{Fe}_{\text {tot }}$, special spectrophotometers were used. For $\mathrm{Cr}_{\text {tot }}$ and $\mathrm{SiO}_{2}$ estimations, a DR 2700 instrument was used.

\subsection{Isotopic Ratios}

The instrument which was used for isotopic determination was an IsotopX "Phoenix" multi-collector (Thermal Ionization Mass Spectrometer-TIMS (Middlewhich, UK)). The analyses took place in the Department of Geoscience and Natural Resource Management, at the University of Copenhagen.

\subsubsection{Stable Isotopes of Chromium}

For the chromium isotopes composition, the following method, described in detail, was used: $10 \mathrm{~mL}$ of water aliquots were spiked with an appropriate amount of ${ }^{500} \mathrm{Cr}-{ }^{54} \mathrm{Cr}$ double spike and dried on a hotplate. After addition of $1 \mathrm{~mL}$ of aqua regia, followed by renewed drying and uptake in $1 \mathrm{~mL} 6 \mathrm{~N} \mathrm{HCl}$, the sample solutions were diluted to $0.5 \mathrm{M} \mathrm{HCl}$ with MQ water and passed over $8 \mathrm{~mL}$ stem volume columns charged with 100-200 mesh AG-50W cation resin. $\mathrm{Cr}$ was eluted in $0.5 \mathrm{~N} \mathrm{HCl}$ in an elution scheme based on a particular recipe [59]. The procedure yields for $\mathrm{Cr}$ in this separation method varied from $70-80 \%$, and Cr procedure blanks were in the order of 5-10 ng, which is negligible compared to the amount of chromium separated from the samples studied herein.

The addition of a ${ }^{50} \mathrm{Cr}-{ }^{54} \mathrm{Cr}$ double spike of known isotope composition to a sample before chemical purification allowed accurate correction of both the chemical and the instrumental shifts in Cr isotope abundances [21,43]. Thanks to this method, we achieve a $2 \mathrm{~s}$ external reproducibility of the $\delta^{53} \mathrm{Cr}$ value with $1.5 \mathrm{mg} \mathrm{Cr}$ loads of the NIST SRM 3112a standard on an IsotopX/GV IsoProbeT thermal ionization mass spectrometer (TIMS) of $\pm 0.05 \%$ with ${ }^{52} \mathrm{Cr}$ signal intensities of $1 \mathrm{~V}$ and of $\pm 0.08 \%$ o for ${ }^{52} \mathrm{Cr}$ beam intensities of $500 \mathrm{mV}$. The double spike correction returns $\mathrm{Cr}$ isotope compositions of samples as the per mil difference to the isotope composition of the NIST SRM 3112a Cr standard (used for the spike calibration; [21]).

To maintain inter-laboratory comparability of Cr isotope data, we recalculated our data of natural samples relative to the certified Cr isotope standard NIST SRM 979 as follows:

$$
\delta^{53} \mathrm{Cr} \text { sample (SRM 979) }=\left[\left({ }^{53} \mathrm{Cr} /{ }^{52} \mathrm{Cr} \text { sample } /{ }^{53} \mathrm{Cr} /{ }^{52} \mathrm{Cr} \text { SRM 979 }\right)-1\right] \times 1000
$$

Cr isotope measurements were performed on an IsotopX/GV IsoProbe T TIMS equipped with eight Faraday collectors that allow simultaneous collection of all four chromium beams $\left({ }^{500} \mathrm{Cr}^{+},{ }^{52} \mathrm{Cr}^{+}\right.$, ${ }^{53} \mathrm{Cr}^{+},{ }^{54} \mathrm{Cr}^{+}$) together with ${ }^{49} \mathrm{Ti}^{+},{ }^{51} \mathrm{~V}^{+}$, and ${ }^{56} \mathrm{Fe}^{+}$to monitor for small interferences of these masses on ${ }^{500} \mathrm{Cr}$ and ${ }^{54} \mathrm{Cr}$.

\subsubsection{Strontium Isotopic Measurements}

The method used to determine the ${ }^{87} \mathrm{Sr} /{ }^{86} \mathrm{Sr}$ ratios, is described in detail. Water aliquots were filtered with disposable syringe filters $(0.45 \mathrm{~lm})$ and between 2 and $4 \mathrm{~mL}$ aliquots were transferred to $7 \mathrm{~mL}$ Teflon (Savillex ${ }^{\mathrm{TM}}$ ) vials. The aliquots were evaporated down on a hotplate at $80{ }^{\circ} \mathrm{C}$ overnight. Samples were taken up in a few drops of $3 \mathrm{M} \mathrm{HNO}_{3}$ and then loaded on 
commercially available (Eppendorf ${ }^{\mathrm{TM}}$ ) $1 \mathrm{~mL}$ pipette tips with a pressed-in filter designed to be used as an extraction column. These "columns" were charged with $200 \mu \mathrm{L}$ of an intensively pre-cleaned mesh 50-100 Sr Spec ${ }^{\mathrm{TM}}$ (Eichrome Inc./Tristchem, Chicago, IL, USA), resin and an appropriate elution recipe essentially was followed [60]. Strontium was eluted/stripped by pure deionized water and then the eluate was dried on a hotplate. Samples were dissolved in $2.5 \mathrm{~L}$ of a $\mathrm{Ta}_{2} \mathrm{O}_{5}-\mathrm{H}_{3} \mathrm{PO}_{4}-\mathrm{HF}$ activator solution and loaded directly onto previously outgassed $99.98 \%$ single Re filaments. Samples were measured at $1250-1300{ }^{\circ} \mathrm{C}$ in dynamic multi-collection mode on a VG Sector 54 IT mass spectrometer (Middlewhich, UK) equipped with eight Faraday detectors. Five ng loads of the NBS 987. Sr standard gave ${ }^{87} \mathrm{Sr} /{ }^{86} \mathrm{Sr}=0.710236 \pm 0.000010(n=14,2 \mathrm{~s})$.

The ${ }^{87} \mathrm{Sr} /{ }^{86} \mathrm{Sr}$ values of the samples were corrected for the offset relative to the certified NIST SRM 987 value of 0.710250 . The errors reported are within-run $(2 \mathrm{sm})$ precisions of the individual runs.

\section{Results and Discussion}

In Table 1, the descriptive statistics of all the measured values, i.e., their units, their average, their standard deviation, the minimum and maximum values and the number $(\mathrm{N})$ of the measured samples are presented. In the following paragraphs, the results are presented in detail.

Table 1. Descriptive statistics of chemical analyses of the dry period of 2012.

\begin{tabular}{ccccccc}
\hline Parameter & Unit & Average & St. Dev. & Min. & Max. & N \\
\hline $\mathrm{Cond}$ & $\mu \mathrm{s} / \mathrm{cm}$ & 736.6 & 119.7 & 466 & 957 & 20 \\
$\mathrm{D.O}$. & $\mathrm{mg} / \mathrm{L}$ & 8.89 & 4.2 & 2.4 & 14.4 & 20 \\
$\mathrm{pH}$ & & 8.18 & 1.2 & 7.4 & 9.41 & 20 \\
$\mathrm{Eh}$ & $\mathrm{mV}$ & 157.65 & 60.3 & 80 & 268 & 20 \\
$\mathrm{~T}$ & ${ }^{\circ} \mathrm{C}$ & 21 & 0.4 & 20 & 21.9 & 20 \\
$\mathrm{~F}^{-}$ & $\mathrm{mg} / \mathrm{L}$ & 0.2 & 0.1 & 0.1 & 0.5 & 19 \\
$\mathrm{Cl}^{-}$ & $\mathrm{mg} / \mathrm{L}$ & 42 & 18.7 & 16 & 80.9 & 20 \\
$\mathrm{Br}^{-}$ & $\mathrm{mg} / \mathrm{L}$ & 1.2 & 0.2 & 0.9 & 1.7 & 20 \\
$\mathrm{NO}_{3}{ }^{-}$ & $\mathrm{mg} / \mathrm{L}$ & 44.9 & 36.9 & 4.6 & 145 & 20 \\
$\mathrm{SO}_{4}^{-}$ & $\mathrm{mg} / \mathrm{L}$ & 12.5 & 9.8 & 3.3 & 45.7 & 20 \\
$\mathrm{HCO}_{3}{ }^{-}$ & $\mathrm{mg} / \mathrm{L}$ & 375.5 & 66.5 & 280 & 540 & 20 \\
$\mathrm{Na}^{+}$ & $\mathrm{mg} / \mathrm{L}$ & 26 & 9.2 & 10 & 50.3 & 20 \\
$\mathrm{~K}^{+}$ & $\mathrm{mg} / \mathrm{L}$ & 1.7 & 2.5 & 0.2 & 9.9 & 20 \\
$\mathrm{Ca}^{2+}$ & $\mathrm{mg} / \mathrm{L}$ & 25 & 26.4 & 2.9 & 92.6 & 20 \\
$\mathrm{Mg}^{2+}$ & $\mathrm{mg} / \mathrm{L}$ & 81.1 & 20.1 & 42 & 122 & 20 \\
$\mathrm{SiO}$ & $\mathrm{mg} / \mathrm{L}$ & 36.1 & 21.6 & 13 & 87 & 20 \\
$\mathrm{Cr}_{2}(\mathrm{VI})$ & $\mu \mathrm{g} / \mathrm{L}$ & 80.8 & 79.2 & 3 & 255 & 20 \\
$\mathrm{Zn}$ & $\mu \mathrm{L} / \mathrm{L}$ & 137.4 & 341.2 & 19 & 1500 & 18 \\
$\mathrm{~Pb}^{2}$ & $\mu \mathrm{g} / \mathrm{L}$ & 13 & 4.6 & 3 & 19.4 & 18 \\
$\mathrm{Cu}$ & $\mu \mathrm{g} / \mathrm{L}$ & 8.8 & 17 & 2.2 & 75.6 & 18 \\
\hline
\end{tabular}

\subsection{Physicochemical Properties}

The groundwater of the area is characterized by relatively increased electric conductivity with a mean value of $736 \mu \mathrm{S} / \mathrm{cm}$. and temperature $\left(20.1-21.9^{\circ} \mathrm{C}\right)$. All $\mathrm{pHs}$ are relatively alkaline and the average $\mathrm{pH}$ is 8.19 in the east part of the study area. Redox values are positive and between 80 and $267 \mathrm{mV}$ (average $157.65 \mathrm{mV}$ ). D.O. (2.4-14.4 mg/L) is also present with an average value of $8.9 \mathrm{mg} / \mathrm{L}$. The average values of $\mathrm{Eh}$ and $\mathrm{pH}$ are depicted in the $\mathrm{Cr}(\mathrm{OH})_{3}$ field which means that redox conditions favor natural attenuation, as shown in Figure 4. Increased $\mathrm{pH}$ values wer e evident (2012 dry period) due to the occurrence of peridotites which favor alkali conditions while in the west part they are slightly lower. 


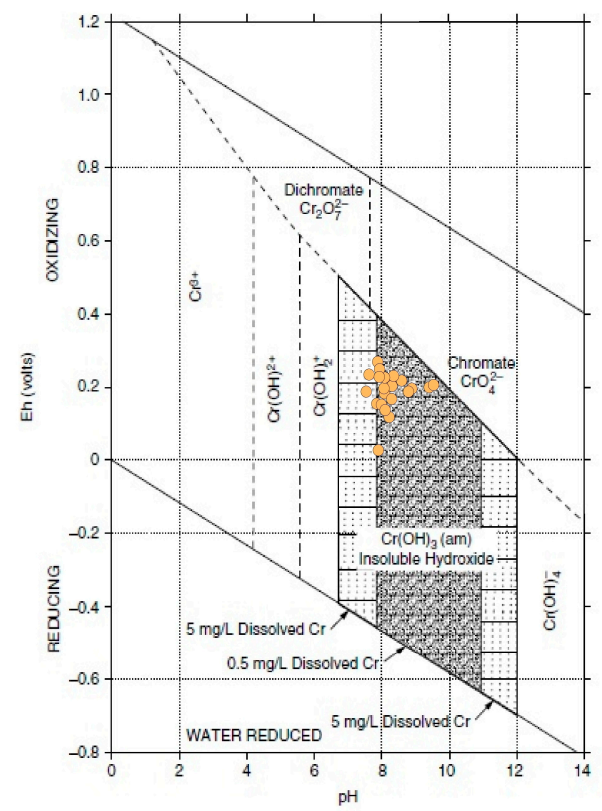

Figure 4. In situ redox conditions in the study area.

\subsection{Anions and Cations}

Chlorine concentrations range from 16 to $80 \mathrm{mg} / \mathrm{L} . \mathrm{HCO}_{3}{ }^{-}$is stable between $\mathrm{pH} 6.5$ and 11 and it is the dominant anion with an average concentration of $375 \mathrm{mg} / \mathrm{L}$ (Table 1). One of the characteristics of Thebes Basin is the deterioration of water quality from nitrates $\mathrm{NO}_{3}{ }^{-}(4.6-144.5 \mathrm{mg} / \mathrm{L})$. The average value is about $36.9 \mathrm{mg} / \mathrm{L}$ but the maximum value exceeds by far the E.U. and state guideline of $50 \mathrm{mg} / \mathrm{L}$ [11-13]. Sulfates are also present and their average concentration is $12.5 \mathrm{mg} / \mathrm{L}$.

Sodium concentrations in the study area range from 10.4 to $50.3 \mathrm{mg} / \mathrm{L}$. Potassium $(0.2-9.9 \mathrm{mg} / \mathrm{L})$ may originate from specific rocks, but also from fertilizes used in agricultural activities. Calcium (3-92 mg/L) concentrations may be generated from carbonate rocks and igneous rocks rich in calcite minerals. High magnesium concentrations (41-121 mg/L) are attributed to the dissolution of the minerals contained in the ophiolite mélanges and the occurrence of dolomites in the study area.

The dominant water type among the 20 samples is $\mathrm{Mg}-\mathrm{HCO}_{3}$. It is obvious that magnesium plays an important role in the groundwater chemistry of the area. The $\mathrm{Mg} / \mathrm{Ca}$ ratio was $>1$ in all samples, which is an indicator that the ophiolites and their eroded materials are the source of magnesium [61]. The water types and the dominance of magnesium over calcium are depicted in the Piper and Durov (expanded) diagram of Figure 5.
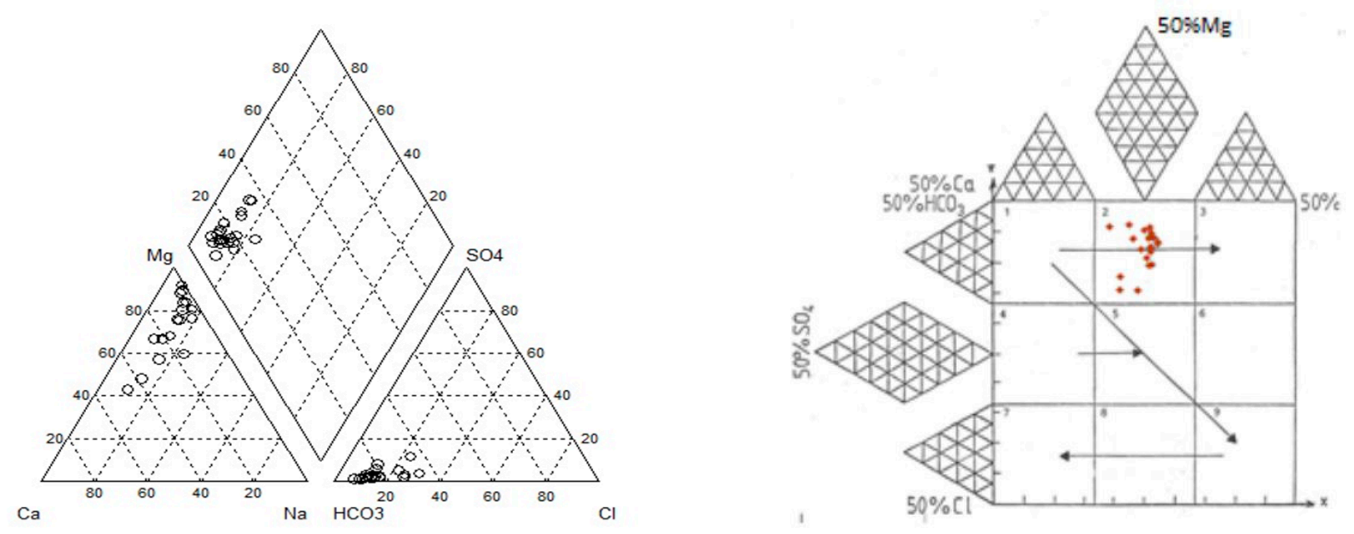

Figure 5. Piper and Durov diagrams. 


\subsection{Trace Elements and $\mathrm{SiO}_{2}$}

Fluorine and bromide are present as trace elements and their averages are $0.2 \mathrm{mg} / \mathrm{L}$ and $1.2 \mathrm{mg} / \mathrm{L}$, respectively. $\mathrm{SiO}_{2}$ concentration varies between 13 and $87 \mathrm{mg} / \mathrm{L}$. The $\mathrm{SiO}_{2}$ detection indicates silicate rock leaching.

Another point which must be highlighted was that neither $\mathrm{Mn}^{2+}$ nor $\mathrm{Fe}_{\text {tot }}$ were detectable by our methods. The detection limit of $\mathrm{Mn}^{2+}$ was $0.1 \mathrm{ppb}$ in the ion chromatograph and $\mathrm{Fe}_{\text {tot }} 1 \mathrm{ppb}$ in the spectrophotometer.

\subsection{Heavy Metals and Chromium}

$\mathrm{Pb}, \mathrm{Zn}$ and $\mathrm{Cu}$ (usually divalent) do not change oxidation states in the environment [31], are not considered redox-sensitive and they do not tend to attenuate as $\mathrm{Cr}$ (VI) by the redox conditions. Their average values are below the E.U. guidelines [12].

Cr (VI) concentrations range between 3 and $255 \mu \mathrm{g} / \mathrm{L}$ and 12 out of 20 samples exceed the E.U. guideline of $50 \mu \mathrm{g} / \mathrm{L}$ for $\mathrm{Cr}_{\text {tot }}$ and these waters are classed as unsuitable for human consumption [11-13]. The Plain is polluted in the east and the west part with $\mathrm{Cr}$ (VI). Generally, the Mouriki zone with the peridotites has small $\mathrm{Cr}(\mathrm{VI})$ concentrations (nitrates distribution is also presented). The point distribution of $\mathrm{Cr}(\mathrm{VI})$ concentrations is presented in Figure 6. This figure also includes spatial contribution of the nitrates which is another pollutant factor.

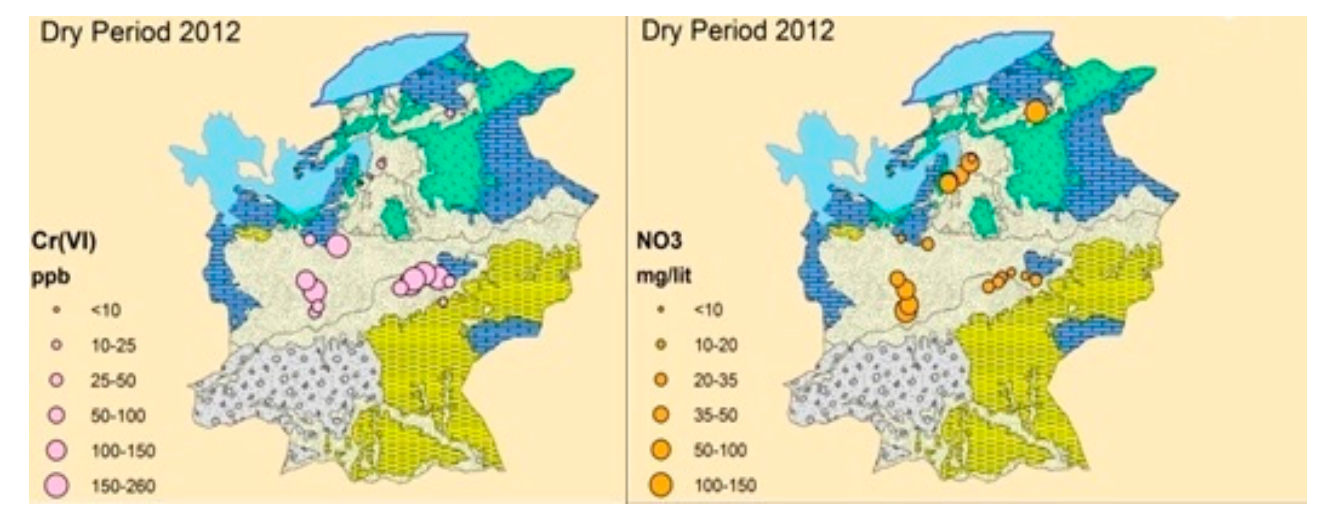

Figure 6. $\mathrm{Cr}(\mathrm{VI})$ and $\mathrm{NO}_{3}{ }^{-}$concentrations in the polluted areas of Thebes.

\subsection{Isotopic Compositions}

The samples were measured for stable chromium isotopes and total chromium values were measured, as shown in Table 2. It should be mentioned that isotopic determination took place in 12 out of 20 samples. In those cases, the samples with the highest $\mathrm{Cr}(\mathrm{VI})$ concentration were chosen. The issue of magnesium and the hypothesis of peridotites led to the idea of strontium isotopes, the results of which are presented in Table 2.

All the $\delta^{53} \mathrm{Cr}$ values are positive; the samples 1 to 7 are from the east part while the samples from 7 to 13 are from the west part. In the east part of the area, the $\delta^{53} \mathrm{Cr}$ is slightly higher than in the west part. The positive $\delta^{53} \mathrm{Cr}$ values indicate the geogenic origin of $\mathrm{Cr}(\mathrm{VI})$. However, we must be very careful because several samples contain considerable amounts of $\mathrm{Cr}$ (III). The presence of $\mathrm{Cr}$ (III) indicates natural attenuation of $\mathrm{Cr}(\mathrm{VI})$ and therefore considerable fractionation, especially in the west part of the study.

A figure of $\mathrm{Cr}(\mathrm{VI})$ vs. $\delta^{53} \mathrm{Cr}$ values has been constructed (Figure 7), illustrating that the east part of the area is not only high in $\mathrm{Cr}(\mathrm{VI})$ concentrations, but also higher $\delta^{53} \mathrm{Cr}$ values show the impact of peridotites. The isotopic $\mathrm{Cr}$ ratios vary between 0.62 and 1.1 and there is an extraordinary value at 1.99 due to fractionation. 
Sr ratios have an average value of 0.7089996 which is suitable for leachates of fertilizers or limestones. Since limestones do not control the groundwater chemistry (due to magnesium dominance), the most probable scenario is that such ratios originate from the first cause. The increased nitrate concentrations indicate fertilizer leaching in the study area. A plot of Sr ratios vs. nitrates has been plotted in Figure 8 in order to testify the relation between them, as shown in Figure 4 . The ${ }^{87} \mathrm{Sr} /{ }^{86} \mathrm{Sr}$ ratios are between 0.708807 and 0.709088 . Additionally, an extraordinary value at 0.709394 has been reported. The highest nitrate values are mainly between 0.708911 and $0.708956{ }^{87} \mathrm{Sr} /{ }^{86} \mathrm{Sr}$ ratios. This shows a preference of high nitrates concentrations for these values. Also, it is notable that high nitrate values are gathered in the west part of the study area.

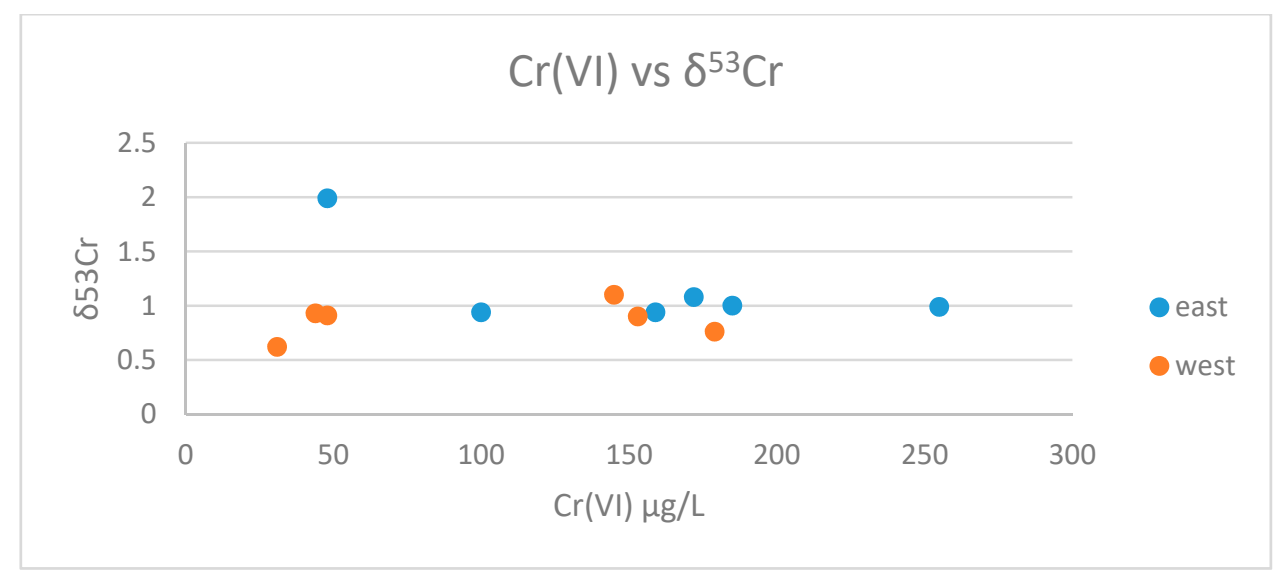

Figure 7. $\mathrm{Cr}(\mathrm{VI})$ vs. $\delta^{53} \mathrm{Cr}$ plot.

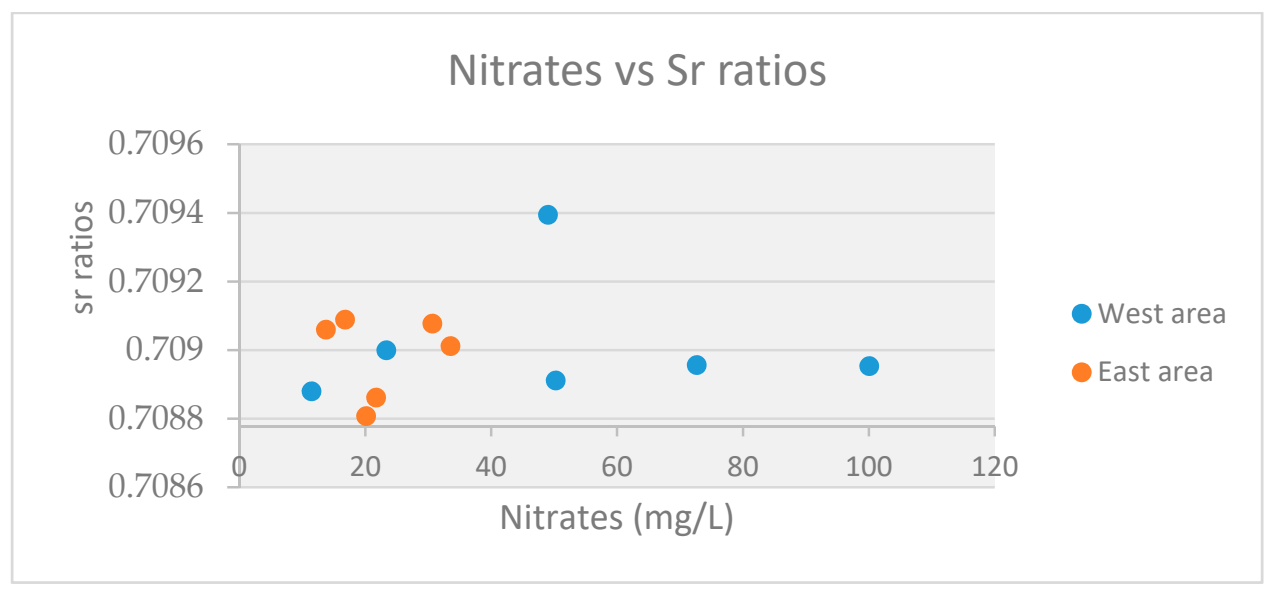

Figure 8. $\mathrm{NO}_{3}$ vs. ${ }^{87} \mathrm{Sr} /{ }^{86} \mathrm{Sr}$ ratios, plot.

Table 2. $\mathrm{Cr}$ (tot) and $\mathrm{Cr}(\mathrm{VI})$ concentrations and isotopic determination.

\begin{tabular}{ccccccc}
\hline Sample & $\mathbf{C r}_{\text {tot }}(\boldsymbol{\mu g} / \mathbf{L})$ & $\mathbf{C r}(\mathbf{V I})(\boldsymbol{\mu g} / \mathbf{L})$ & $\mathbf{C r}(\mathbf{V I}) / \mathbf{C r}_{\text {tot }} \%$ & $\mathbf{N O}_{\mathbf{3}}{ }^{-}(\mathbf{m g} / \mathbf{L})$ & $\boldsymbol{\delta}^{53} \mathbf{C r}$ & ${ }^{\mathbf{8 7}^{\mathbf{S}} \mathbf{S r}}{ }^{\mathbf{8 6}} \mathbf{S r}$ \\
\hline 1 & 257 & 255 & $0.78 \%$ & 13.773 & 0.99 & 0.709059 \\
3 & 67 & 48 & $28.36 \%$ & 33.558 & 1.99 & 0.709011 \\
4 & 112 & 100 & $10.71 \%$ & 20.142 & 0.94 & 0.708807 \\
5 & 190 & 185 & $2.63 \%$ & 21.736 & 1.00 & 0.708861 \\
6 & 178 & 159 & $10.67 \%$ & 30.664 & 0.94 & 0.709077 \\
7 & 186 & 172 & $7.53 \%$ & 16.823 & 1.08 & 0.709088 \\
8 & 159 & 145 & $8.81 \%$ & 49.046 & 1.10 & 0.709394 \\
9 & 112 & 48 & $57.14 \%$ & 100.084 & 0.91 & 0.708952 \\
10 & 78 & 44 & $43.59 \%$ & 72.678 & 0.93 & 0.708956 \\
\hline
\end{tabular}


Table 2. Cont.

\begin{tabular}{ccccccc}
\hline Sample & $\mathrm{Cr}_{\text {tot }}(\boldsymbol{\mu g} / \mathrm{L})$ & $\mathbf{C r}(\mathrm{VI})(\boldsymbol{\mu g} / \mathrm{L})$ & $\mathbf{C r}(\mathbf{V I}) / \mathbf{C r}_{\text {tot }} \%$ & $\mathbf{N O}_{3}{ }^{-}(\mathbf{m g} / \mathbf{L})$ & $\delta^{53} \mathbf{C r}$ & ${ }^{87} \mathbf{S r} /{ }^{86} \mathbf{S r}$ \\
\hline 11 & 156 & 153 & $1.92 \%$ & 50.261 & 0.90 & 0.708911 \\
12 & 44 & 31 & $29.55 \%$ & 11.473 & 0.62 & 0.708878 \\
13 & 185 & 179 & $3.24 \%$ & 23.348 & 0.76 & 0.708998 \\
Average & 144 & 127 & $17.08 \%$ & 36.96 & 1.01 & 0.708999 \\
\hline
\end{tabular}

\section{Conclusions}

This article focused on the environmental problem of Thebes Plain- $\mathrm{Cr}$ (VI) pollution-and analyzed the possible sources of human and geogenic pollution. In cases of higher C (III) concentrations, fractionation phenomena (due to natural attenuation) take place. In these cases, stable chromium isotopes are not a safe guide. In the case that $\delta^{53} \mathrm{Cr}$ values are positive and $\mathrm{Cr}$ (III) concentrations are not so high, the presence of $\mathrm{Cr}(\mathrm{VI})$ has to be attributed to the geogenic factor.

In the east part of the area, the geogenic contribution is more obvious since the $8^{53} \mathrm{Cr}$ values are higher. Also, the fractionation phenomena are not so intense due to the alkaline conditions that peridotites create. The west part of the area seems to be affected by the human factor due to the numerous recorded anthropogenic pollutant sources. The $\delta^{53} \mathrm{Cr}$ values are closer to zero and we experience fractionation phenomena due to natural attenuation. Table 2 shows that no particular fractionation takes part (see $\mathrm{Cr}(\mathrm{VI}) / \mathrm{Cr}_{\text {tot }} \%$ ) in the east part, while in the west part half of the samples indicate fractionation.

Strontium isotopic ratios gave an average value of 0.708999 . This value could originate from limestones leaching and/or fertilizer leachates. It has already been mentioned that $\mathrm{Mg}$ dominates over Ca and additionally, dolomite limestones such as those of the study area have slightly lower prices. The most important fact, however, is that nitrates are present in the study area, particularly in the west part. The presence of nitrates is an anthropogenic influence, it creates further pollutant problems and it is very possible that their leachates contain $\mathrm{Cr}(\mathrm{VI})$, as several works suggest $[16,30]$.

To conclude, further environmental monitoring should take place and acceptable methods should be applied such as phytoremediation and in situ treatment $[4,16,39]$. The natural attenuation phenomena, particularly in the west part, provide natural remediation and may be used as a basis for future remediation.

Acknowledgments: I wish to thank Robert Frei for the isotopic measurement; Roney Schoenberg for his valuable advice; the researchers and friends Dimitrios Pantazis and Hara Mimidou for their help and support. Last but not least, this article is devoted with gratitude to the memory of Theologos Mimides.

Conflicts of Interest: The author declares no conflict of interest.

\section{References}

1. Bourotte, C.; Bertolo, R.; Almodovar, M.; Hirata, R. Natural occurrence of hexavalent chromium in a sedimentary aquifer in Urania, State of Sao Paulo, Brazil. Ann. Braz. Acad. Sci. 2009, 81, 227-242. [CrossRef]

2. Fantoni, D.; Brozzo, G.; Canepa, M.; Cipolli, F.; Marini, L.; Ottonello, G.; Zuccolini, M.V. Natural hexavalent chromium in groundwaters interacting with ophiolitic rocks. Environ. Geol. 2002, 42, 871-882. [CrossRef]

3. Armenita, M.A.; Quere, A. Hydrogeochemical behavior of chromium in the unsaturated zone and in the aquifer of Leon Valley, Mexico. Water Air Soil Pollut. 1995, 84, 11-29. [CrossRef]

4. Izbiki, J.A.; Ball, J.W.; Bullen, T.D.; Sutley, S.J. Chromium, chromium isotopes and selected trace elements, western Mojave Desert, U.S.A. Appl. Geochem. 2008, 23, 1325-1352. [CrossRef]

5. Dash, P.; Silwal, S.; Ikenga, J.O.; Pinckney, J.L.; Arslan, Z.; Lizotte, R.E. Water Quality of Four Major Lakes in Mississippi, USA: Impacts on Human and Aquatic Ecosystem Health. Water 2015, 7, 4999-5030. [CrossRef] 
6. Potasznik, A.K.; Szymczyk, S.; Skwierawski, A.; Lewczuk, K.G.; Cymes, I. Heavy Metal Contamination in the Surface Layer of Bottom Sediments in a Flow-Through Lake: A Case Study of Lake Symsar in Northern Poland. Water 2016, 8, 358. [CrossRef]

7. Economou-Eliopoulos, M.; Frei, R.; Atsarou, C. Application of chromium stable isotopes to the evaluation of $\mathrm{Cr}(\mathrm{VI})$ contamination in groundwater and rock leachates from central Euboea and the Assopos basin (Greece). Catena 2014, 122, 216-228. [CrossRef]

8. Megremi, I. Distribution and bioavailability of $\mathrm{Cr}$ in central Euboea, Greece. Cent. Eur. J. Geosci. 2009. [CrossRef]

9. Cary, E.E. Chromium in air, soil, and natural waters. Biological and Environmental Aspects of Chromium. In Topics in Environmental Health; Elsevier Biomedical Press: New York, NY, USA, 1982; pp. 49-64.

10. National Institute for Occupational Safety and Health (NIOSH). Online Pocket Guide to Chemical Hazards. NIOSH, 1999. Available online: http:/ / www.cdc.gov/niosh/npg/npg.html (accessed on 8 August 2017).

11. Ljujic, B.; Sundac, Lj. Council Directive 98/83/EC Directive of the European Parliament on the Quality of Water Intended for Human Consumption; The European Parliament and the Council of the European Union, Off J L 330; European Union: Brussels, Belgium, 1998.

12. Word Health Organization (WHO). International Standards for Drinking Water. Switzerland, Italy, 1971. Available online: http://apps.who.int/iris/bitstream/10665/43845/1/a91160.pdf (accessed on 8 August 2017).

13. Michalopoulou, E. Legislation for the Environment; Ziti Publications: Athens, Greece, 2004.

14. Lewis, R.J. Sax's Dangerous Properties of Industrial Materials, 8th ed.; Van Nostrand Reinhold: New York, NY, USA, 1992; Volume II.

15. Thornton, I. Geochemistry applied to agriculture. In Applied Environmental Geochemistry; Academic Press: London, UK, 1983; pp. 231-266.

16. Mimides, Th. Investigation of Agricultural Products for Toxic Pollutants in Thebe's Municipality; Thebe's: Thebs, Greece, 2011.

17. Testa, S. Sources of Chromium Contamination in Soil and Groundwater. In Cr(VI) Handbook; CRC Publications: New York, NY, USA, 2005.

18. Morning, J.L.; Matthews, N.A.; Peterson, E.C. Chromium in Mineral Facts and Problems. In Bulletin 671; U.S. Bureau of Mines: Washington, DC, USA, 1989; pp. 167-182.

19. Hem, J. Study and Interpretation of the Chemical Characteristics of Natural Water, 3rd ed.; U.S.G.S.: Alexandria, VA, USA, 1979.

20. Steinpress, M. Naturally Occurring Chromium(VI) in Groundwater. In Cr(VI) Handbook; CRC Publications: New York, NY, USA, 2005.

21. Schoenberg, R.; Zink, S.; Staubwasser, M.; von Blanckenburg, F. The stable Cr isotope inventory of solid Earth reservoirs determined by double spike MC-ICP-MS. Chem. Geol. 2008, 249, 294-306. [CrossRef]

22. Motzer, W. Chemistry, Geochemistry and Geology of Chromium. In Cr(VI) Handbook; CRC PRESS: New York, NY, USA, 2005.

23. Vasilatos, C.; Megremi, I.; Economou-Eliopoulos, M.; Mitsis, I. Hexavalent chromium and other toxic elements in natural waters in the Thiva-Tanagra-Malakasa Basin, Greece. Hell. J. Geosci. 2008, 43, 57-66.

24. Mimides, T. Management and Protection of the Avlonas Area; Research work; Agricultural University of Athens: Athens, Greece, 2007.

25. Economou-Eliopoulos, M.; Antivachi, D.; Vasilatos, C.; Megremi, I. Evaluation of the Cr (VI) and other toxic element contamination and their potential sources: The case of the Thiva basin (Greece). Geosci. Front. 2011. [CrossRef]

26. Dermatas, D.; Vatseris, C.; Panagiotakis, I.; Chrysochoou, M. Potential Contribution of geogenic chromium in groundwater contamination of a Greek heavily industrialized area. Chem. Eng. Trans. 2012, 28. [CrossRef]

27. Tziritis, E.; Kelepertzis, E.; Korres, G.; Perivolaris, D.; Repani, S. Hexavalent Chromium Contamination in Groundwaters of Thiva Basin, Central Greece. Environ. Contam. Toxicol. 2012, 89, 1073-1077. [CrossRef] [PubMed]

28. Institute of Geological and Mineral Exploration of Greece (IGME). Pollution Factors in Boeotia Prefecture (E.U. Project); IGME: Athens, Greece, 2010. 
29. Raddatz, A.L.; Johnson, T.M.; MicLing, T.L. Cr stable isotopes in Snake River Plain Aquifer groundwater: Evidence for natural reduction of dissolved Cr (VI). Environ. Sci. Technol. 2011, 45, 502-507. [CrossRef] [PubMed]

30. Mimides, T. Hydrogeochemical Autopsy of Stable Chromium Isotopes in Order to Investigate Its Human and Natural Origin; Euboea-Psachna (Technical Report); Agricultural University of Athens: Athens, Greece, 2015.

31. Mathess, J. The Properties of Groundwater; Willey Publications: New York, NY, USA, 1995.

32. Mimides, T.; Koilakos, D. Soil chemistry of Boeotia prefecture and application of Yttrium normalization theory for explaining the origin of chromium in soil. In Proceedings of the CRETE 2014 Conference, Chania, Greece, 7-10 September 2014.

33. Richard, F.C.; Bourg, A.C. Aqueous geochemistry of chromium: A review. Water Resour. 1991, 25, 807-816. [CrossRef]

34. Stanin, F. The Transport and Fate of Chromium (VI) in the Environment. In Hexavalent Chromium Handbook; CRC Publications: New York, NY, USA, 2005.

35. Schroeder, D.; Lee, F. Potential Transformations of Chromium in Natural Waters; Institute for Environmental Sciences; University of Texas-Dallas: Richardson, TX, USA, 1974.

36. Bartlett, R.J. Chromium cycling in soils and water: Links, gaps, and methods. Environ. Health Perspect. 1991, 92, 17-24. [CrossRef] [PubMed]

37. Fendorf, S.E.; Zasoski, R.J. Chromium(III) oxidation by $\mathrm{MnO}_{2}$, part 1. characterization. Environ. Sci. Technol. 1992, 26, 79-85. [CrossRef]

38. Balance Chemical Equation-Online Balancer. Available online: http://www.webqc.org/balance.php (accessed on 9 August 2017).

39. Davis, A.; Olsen, R.L. The geochemistry of chromium migration and remediation in the subsurface. Ground Water 1995, 33, 759-768. [CrossRef]

40. Rai, D.; Sass, B.M.; Moore, D.A. Chromium(III) hydrolysis constants and solubility of chromium(III) hydroxide. Inorg. Chem. 1987, 26, 345-349. [CrossRef]

41. Stollenwerk, K.G.; Grove, D.B. Adsorption and desorption of hexavalent chromium in an alluvial aquifer near Telluride, Colorado. J. Environ. Qual. 1985, 14, 150-155. [CrossRef]

42. Viamajala, S.; Peyton, B.M.; Apel, W.A.; Petersen, J.N. Chromate reduction in shewanella oneidensis MR-1 is an inducible process associated with anaerobic growth. Biotechnol. Prog. 2002, 18, 290-295. [CrossRef] [PubMed]

43. Ellis, A.S.; Johnson, T.M.; Bullen, T.D. Chromium isotopes and the fate of hexavalent chromium in the environment. Environ. Sci. 2002, 295, 2060-2062. [CrossRef] [PubMed]

44. Johnson, T.M. Stable Isotopes of $\mathrm{Cr}$ and Se as Tracers of Redox Processes in Earth Surface Environments; Springer: Berlin, Germany, 2011; p. 239.

45. Barbieri, M.; Boschetti, T.; Petitta, M.; Tallini, M. Stable isotope $\left({ }^{2} \mathrm{H},{ }^{18} \mathrm{O}\right.$ and $\left.{ }^{87} \mathrm{Sr} /{ }^{87} \mathrm{Sr}\right)$ and hydrochemistry monitoring for groundwater hydrodynamics analysis in a karst aquifer (Gran Sasso, Central Italy). Appl. Geochem. 2005. [CrossRef]

46. Barbieri, M.; Morotti, M. Hydrogeochemistry and strontium isotopes of spring and mineral waters from Monte Vulture volcano, Italy. Appl. Geochem. 2003, 18, 117-125. [CrossRef]

47. Barbieri, M.; Nigro, A.; Petitta, M. Groundwater mixing in the discharge area of San Vittorino Plain (Central Italy): Geochemical characterization and implication for drinking uses. Environ. Earth Sci. 2017. [CrossRef]

48. Negrel, P.; Roy, S. Rain chemistry in the Massif Central (France). A strontium isotopic and major elements study. Appl. Geochem. 1998, 13, 941-952. [CrossRef]

49. Brass, G. The variation of the marine ${ }^{87} \mathrm{Sr} /{ }^{86} \mathrm{Sr}$ ratio during Phanerozoic time: Interpretation using a flux model. Geoch. Cosmoch. Acta 1978, 40, 721-730. [CrossRef]

50. Dotsika, E.; Poutoukis, D.; Kloppmann, W.; Guerrot, C.; Voutsa, D.; Kouimtzis, T.H. The use of O, H, B, $\mathrm{Sr}$ and $\mathrm{S}$ isotopes for tracing the origin of dissolved boron in groundwater in Central Macedonia, Greece. Appl. Geochem. 2010. [CrossRef]

51. Negrel, P.; Dupre, B.; Seimbille, F.; Allegre, C.J. Quantitative modelisation of differential erosion between crystalline and sedimentary area of a French basin by isotopic analysis of strontium in river waters. Chem. Geol. 1988, 70, 13. [CrossRef] 
52. Negrel, P.; Deschamps, P. Natural and anthropogenic budgets of a small watershed in the Massif Central (France): Chemical and strontium isotopic and major elements study. Aquat. Geochem. 1997, 2, 1-27. [CrossRef]

53. Institute of Geological and Mineral Exploration of Greece (IGME). Thebes Sheet; IGME: Athens, Greece, 1967.

54. Koumantakis, I. Hydrogeological Conditions of Thebes Basin Athens-Greece; NTUA: Athens, Greece, 1980.

55. Parks, J.L.; Mc Neill, L.; Frey, M.; Eaton, A.D.; Haghani, A.; Ramirez, L.; Edwards, M. Determination of total chromium in environmental water samples. Water Res. 2004, 38, 2827-2838. [CrossRef] [PubMed]

56. METROHM. Introduction to Polarography and Voltammetry; Metrohm: Stockholm, Sweden, 2010.

57. METROHM. Ion Analysis, Chromium in Waste Water; Metrohm: Stockholm, Sweden, 2010.

58. Hach. DR 2800 Spectrophotometer; Hach: Dusseldorf, Germany, 2007.

59. Trinquier, A.; Elliott, T.; Ulfbeck, D.; Coath, C.; Krot, A.N.; Bizzarro, M. Origin of nucleosynthetic isotope heterogeneity in the solar protoplanetary disk. Science 2009, 324, 374-376. [CrossRef] [PubMed]

60. Horwitz, E.P.; Dietz, M.L.; Fisher, D.E. Separation and preconcentration of strontium from biological, environmental, and nuclear waste samples by extraction chromatography using a crown ether. Anal. Chem. 1991. [CrossRef]

61. Soulios, G. General Hydrogeology_Volume 4; University Studio Press: Thesaloniki, Greece, 2006.

(C) 2017 by the author. Licensee MDPI, Basel, Switzerland. This article is an open access article distributed under the terms and conditions of the Creative Commons Attribution (CC BY) license (http:/ / creativecommons.org/licenses/by/4.0/). 